Correspondence

Abdul Majid Maszenan cmaszenan@ntu.edu.sg

\section{Granulicoccus phenolivorans gen. nov., sp. nov., a Gram-positive, phenol-degrading coccus isolated from phenol-degrading aerobic granules}

\author{
Abdul Majid Maszenan, ${ }^{1}$ He Long Jiang, ${ }^{1}$ Joo-Hwa Tay, ${ }^{1}$ \\ Peter Schumann, ${ }^{2}$ Reiner M. Kroppenstedt ${ }^{2}$ \\ and Stephen Tiong-Lee Tay ${ }^{1} \dagger$
}

\author{
${ }^{1}$ Environmental Engineering Research Centre, School of Civil and Environmental Engineering, \\ Nanyang Technological University, Singapore 639798 \\ ${ }^{2} \mathrm{DSMZ}$ - Deutsche Sammlung von Mikroorganismen und Zellkulturen GmbH, Inhoffenstr. 7b, \\ D-38124 Braunschweig, Germany
}

\begin{abstract}
A Gram-positive bacterium, designated strain $\mathrm{PG}-02^{\top}$, was isolated by serial dilution from aerobic granules obtained from a laboratory-scale sequencing batch reactor for bioremediation of phenolic wastewater. Strain PG- $02^{\top}$ grew axenically as cocci and is an oxidase-negative and catalase-positive, non-motile facultative anaerobe. It does not reduce nitrate and grows between 15 and $37^{\circ} \mathrm{C}$, with an optimum temperature of $30^{\circ} \mathrm{C}$. The $\mathrm{pH}$ range for growth is between 5.0 and 8.5, with an optimum $\mathrm{pH}$ of 7.0. Strain PG-02 $2^{\top}$ contains type $A 3 \gamma$ peptidoglycan (LL-A 2 pm $\leftarrow$ Gly with alanine at position 1 of the peptide subunit). The $G+C$ content of the DNA is $69 \mathrm{~mol} \%$. Menaquinone MK-9 $\left(\mathrm{H}_{4}\right)$ was the major isoprenoid quinone. The polar lipids included diphosphatidylglycerol and phosphatidylglycerol, while 13-methyltetradecanoic acid (i-C $\mathrm{C}_{15: 0}$ ) and 1,1-dimethoxy-iso-pentadecane ( $i-\mathrm{C}_{15}$ : o $\mathrm{DMA}$ ) were the major components in whole-cell methanolysates. PG- $02^{\top}$ stained positively for intracellular polyphosphate granules but not poly- $\beta$-hydroxyalkanoates. It produces capsular material and possesses an autoaggregation capability. Phenotypic and $16 \mathrm{~S}$ rRNA gene sequence analyses showed that PG-02 ${ }^{\top}$ differed from its closest phylogenetic relatives, namely members of the suborder Propionibacterineae, which includes the genera Tessaracoccus, Microlunatus, Luteococcus, Micropruina, Propionibacterium, Propioniferax, Nocardioides, Friedmanniella and Aeromicrobium, and that it should be placed in a new genus and species as Granulicoccus phenolivorans gen. nov., sp. nov. The type strain of Granulicoccus phenolivorans is PG-02 ${ }^{\top}$ (=ATCC BAA- $1292^{\top}=\mathrm{DSM} 17626^{\top}$ ).
\end{abstract}

Natural phenolic compounds and their derivatives are present in the environment and some enter as intermediates from the biodegradation of natural polymers containing aromatic rings, such as lignins and tannins, aromatic amino acid precursors (Jeong et al., 2003) and xenobiotic compounds (van Schie \& Young, 1998). Due to their wide usage in agricultural and industrial processes, phenol and its derivatives are pollutants of environmental concern (Jensen, 1996). Phenol pollution is often associated with pulp mills, coal mines, cooking plants, oil refineries, industrial resin

tDeceased 29 July 2005.

Abbreviations: $\mathrm{A}_{2} \mathrm{pm}$, diaminopimelic acid; DMA, dimethyl acetal.

The GenBank/EMBL/DDBJ accession number for the 16S rRNA gene sequence of strain $\mathrm{PG}-02^{\top}$ is $\mathrm{AY} 566575$.

Details of signature nucleotides within the 16S rRNA gene sequences of strain $\mathrm{PG}-02^{\top}$ and related taxa are available as supplementary material in IJSEM Online. manufacturing and wood preservation processes and their wastewater (Semple \& Cain, 1995; Selvaratnam et al., 1997; Whiteley \& Bailey, 2000). In the absence of proper treatment, industrial and agricultural effluents can be an important source of anthropogenic phenol. This, together with the acute toxicity of phenols, has led them to be included as priority pollutants for both the World Health Organization and the US Environmental Protection Agency (Davì \& Gnudi, 1999).

The influx of phenol and its derivatives into waste-treatment systems may inhibit microbial activity and result in deterioration of treatment performance and, in extreme cases, complete breakdown of wastewater treatment (Soda et al., 1998; Watanabe et al., 1999). Biodegradation of phenol and phenolics in waste and wastewater is known to be carried out by bacteria of diverse phylogeny, including members from both the Betaproteobacteria and Gammaproteobacteria (Dapaah \& Hill, 1992; Arai et al., 
1998; Whiteley \& Bailey, 2000). Some of these have been isolated and characterized (Hino et al., 1998; Watanabe et al., 1996, 1998; Whiteley \& Bailey, 2000; Rehfuss \& Urban, 2005). The ability of bacteria to aggregate is important in the bioremediation of toxic chemicals such as phenol in the activated sludge process, since those capable of aggregation will be retained in the system through biomass recycling and be protected from predatory protozoa (van Limbergen et al., 1998; Farrell \& Quilty, 2002). Several factors such as substrate gradients, slow growth rates, stress and predation have been suggested to trigger aggregation, although the precise mechanism is not known (Bossier \& Verstraete, 1996).

Aerobic granulation, which represents a novel form of cell immobilization without a carrier matrix, was recently used successfully to treat phenolic wastewater at a load that would lead to failure in conventional activated sludge systems (Jiang et al., 2004). It was thought that aggregation of microbial cells into compact granules protected the organisms from possible phenol toxicity (Jiang et al., 2004). In this study, the description of strain PG- $02^{T}$, one of several phenol degraders that were isolated from these granules, is presented.

Phenol-degrading aerobic granules were cultivated in a laboratory-scale sequencing batch reactor from activated sludge seed, fed with synthetic wastewater containing phenol as the sole carbon source (Jiang et al., 2004). Granules were harvested 8 weeks after steady-state reactor operation. Granules $(2.5 \mathrm{~g})$ were added to $15 \mathrm{ml} \mathrm{MP}$ medium, which contained $\left(\mathrm{l}^{-1}\right) 1.0 \mathrm{~g}\left(\mathrm{NH}_{4}\right)_{2} \mathrm{SO}_{4}, 0.2 \mathrm{~g}$ $\mathrm{MgCl}_{2} \cdot 6 \mathrm{H}_{2} \mathrm{O}, 0.1 \mathrm{~g} \mathrm{NaCl}, 0.02 \mathrm{~g} \mathrm{FeCl}_{3} \cdot 6 \mathrm{H}_{2} \mathrm{O}, 0.01 \mathrm{~g} \mathrm{CaCl}_{2}$ and phosphate buffer ( $1.35 \mathrm{~g} \mathrm{KH}_{2} \mathrm{PO}_{4}$ and $\left.1.65 \mathrm{~g} \mathrm{~K}_{2} \mathrm{HPO}_{4}\right)$, with trace elements and vitamins as described by Cote \& Gherna (1994). The supernatant was serially diluted with medium from $10^{-1}$ to $10^{-7}$ dilutions and $150 \mu \mathrm{l}$ aliquots of each dilution was spread onto agar plates containing MP medium solidified with $1.2 \%$ Bacto agar (Difco). Plates were incubated at $25^{\circ} \mathrm{C}$ and monitored for 4 weeks for colony growth by examination on a colony counter. Visible colonies were observed after 1 week of incubation. Strain PG- $02^{\mathrm{T}}$ takes 10 days to produce visible colonies on MP agar plates. Culture purity was confirmed by microscopic examination of cells taken from single colonies. An axenic culture of strain PG- $02^{\mathrm{T}}$ was preserved at $-80^{\circ} \mathrm{C}$ in MP medium containing $20 \%$ glycerol.

PG- $02^{\mathrm{T}}$ is a facultative anaerobe, as growth occurred down the line of inoculation in stab cultures. It grew at $15-37^{\circ} \mathrm{C}$, with optimum growth at $30^{\circ} \mathrm{C}$, and at $\mathrm{pH} 5.0-8.5$, with optimum growth at $\mathrm{pH}$ 7.0. Cells stained Gram-positively with the modified Gram-stain method of Hucker (Smibert \& Krieg, 1994) and this was confirmed by the absence of stringiness with $3 \% \mathrm{KOH}$ treatment (Buck, 1982). No flagella were detected and the motility test confirmed that strain PG-02 ${ }^{\mathrm{T}}$ was non-motile (Smibert \& Krieg, 1994). Polyphosphate granules were observed by the staining method of Rees et al. (1992) in cells grown aerobically with either glucose, acetate or propionate as the sole carbon source, but polyhydroxyalkanoate granules were not detected when cells were incubated anaerobically. Capsular material was observed with the Indian ink stain.

Physiological and biochemical characteristics of strain PG$02^{\mathrm{T}}$ are presented in the descriptions of the genus and species. Enzyme profiles and biochemical characteristics of strain PG- $02^{\mathrm{T}}$ were determined using the API ZYM and API $20 \mathrm{E}$ systems according to the manufacturer's instructions (bioMérieux). Carbon substrate utilization tests were performed with Biolog GN and GP systems. Cultures were catalase- and urease-positive but oxidase-negative as determined by method of Smibert \& Krieg (1994). The genomic $\mathrm{G}+\mathrm{C}$ content as determined by reversed-phase HPLC (Schumann et al., 1997) was $69 \mathrm{~mol} \%$.

Peptidoglycan, menaquinone and polar lipid compositions were analysed as described by Schumann et al. (1997). Fatty acids were extracted and analysed following the instructions of the Microbial Identification System operating manual (MIDI, 1999) and as described by Kämpfer \& Kroppenstedt (1996). Strain PG- $02^{\mathrm{T}}$ possessed a type A $3 \gamma$ peptidoglycan (LL- $\mathrm{A}_{2} \mathrm{pm} \leftarrow$ Gly with alanine at position 1 of the peptide subunit; type A41.1 according to http://www.dsmz.de/ species/murein.htm). The peptidoglycan amino acids were alanine/glycine/glutamic acid/LL-diaminopimelic acid (LL$\mathrm{A}_{2} \mathrm{pm}$ ) in a molar ratio of $1.5: 0.8: 1.0: 1.0$, as determined by gas chromatography (MacKenzie, 1987). Cells contained two isoprenoid quinones, MK- $9\left(\mathrm{H}_{4}\right)$ and MK- $8\left(\mathrm{H}_{4}\right)$, with a composition ratio of $42: 1$. Polar lipids included diphosphatidylglycerol, phosphatidylglycerol, two unknown glycolipids and three minor phospholipids, and 13-methyltetradecanoic acid (i- $\mathrm{C}_{15: 0}$ ) and 1,1-dimethoxy-iso-pentadecane (i-C $\mathrm{C}_{15: 0}$ DMA) were the two major components of whole-cell methanolysates, respectively contributing 50.5 and $37.4 \%$ to the total. Traces of 12-methyltetradecanoic acid (ai- $\mathrm{C}_{15: 0}$ ), $\mathrm{C}_{12: 0}$ DMA and 9,10-cyclo $\mathrm{C}_{19: 0}$ DMA were also detected (Table 1). 1,1-Dimethoxy-iso-pentadecane (i-C $\mathrm{C}_{15: 0}$ DMA) was identified on the basis of its relative retention times on polar (Varian VF-23ms; $0.25 \mathrm{~mm} \times 30 \mathrm{~m})$ and non-polar (5\% phenyl methyl silicone, $0.2 \mathrm{~mm} \times 25 \mathrm{~m}$ ) gas chromatography columns, and its presence was confirmed by GC-MS using a non-polar OV-1 column $(0.15 \mathrm{~mm} \times 25 \mathrm{~m})$, which revealed fragment ions at $\mathrm{m} / \mathrm{z} 75$ and 241 . When these were compared with the mass spectrum of $\mathrm{i}-\mathrm{C}_{16: 0}$ DMA, which generated a fragment at $\mathrm{m} / \mathrm{z} 255$ (Männistö et al., 2000), the expected mass difference of -14 was observed.

The nearly full-length $16 \mathrm{~S}$ rRNA gene of strain PG-02 ${ }^{\mathrm{T}}$ was amplified and sequenced using methods described previously (Maszenan et al., 1997). A $16 \mathrm{~S}$ rRNA gene sequence of 1320 nucleotides was obtained in both directions, corresponding to positions 20-1471 of the Escherichia coli sequence according to the nomenclature of Winker \& Woese (1991). This sequence was aligned manually against sequences of its close relatives using the alignment editor in BioEdit (Hall, 1997). Sequence analysis was performed 
Table 1. Composition of the whole-cell methanolysate of strain $P G-02^{\top}$

\begin{tabular}{|lc|}
\hline Fatty acid & Content (\%) \\
\hline Tetradecanoic acid $\left(\mathrm{C}_{14: 0}\right)$ & 0.10 \\
Pentadecanoic acid $\left(\mathrm{C}_{15: 0}\right)$ & 0.06 \\
Hexadecanoic acid $\left(\mathrm{C}_{16: 0}\right)$ & 0.26 \\
11-Methyl dodecanoic acid (i- $\left.\mathrm{C}_{13: 0}\right)$ & 0.45 \\
12-Methyl tridecanoic acid (i- $\left.\mathrm{C}_{14: 0}\right)$ & 0.23 \\
13-Methyl tetradecanoic acid (i- $\left.\mathrm{C}_{15: 0}\right)$ & 50.52 \\
14-Methyl pentadecanoic acid (i-C $\left.\mathrm{C}_{16: 0}\right)$ & 0.19 \\
15-Methyl hexadecanoic acid (i- $\left.\mathrm{C}_{17: 0}\right)$ & 0.35 \\
12-Methyl tetradecanoic acid (ai- $\left.\mathrm{C}_{15: 0}\right)$ & 1.80 \\
14-Methyl hexadecanoic acid (ai- $\left.\mathrm{C}_{17: 0}\right)$ & 0.22 \\
1,1-Dimethoxy dodecane $\left(\mathrm{C}_{12: 0}\right.$ DMA) & 5.26 \\
1,1-Dimethoxy tetradecane $\left(\mathrm{C}_{14: 0}\right.$ DMA) & 0.15 \\
1,1-Dimethoxy hexadecane $\left(\mathrm{C}_{16: 0}\right.$ DMA) & 0.18 \\
1,1-Dimethoxy iso-pentadecane (i-C $\left.\mathrm{C}_{15: 0} \mathrm{DMA}\right)$ & 37.42 \\
1,1-Dimethoxy anteiso-pentadecane & 0.31 \\
(ai-C $\mathrm{C}_{15: 0}$ DMA) & \\
1,1-Dimethoxy 9,10-methylene-nonadecane & 2.09 \\
(9,10-cyclo $\mathrm{C}_{19: 0}$ DMA) & \\
\hline
\end{tabular}

with BLAST (Altschul et al., 1997) and CLUSTAL W (Thompson et al., 1994) and SIMILARITY_RANK and SUGGEST_TREE in the Ribosomal Database Project, version 8.0 (Maidak et al., 1997). Distance analysis was performed on a final dataset of an unambiguous alignment of 1162 bases of strain PG- $02^{\mathrm{T}}$ and its closest relatives. A phylogenetic tree was constructed from evolutionary distances using the FITCH program in PHYLIP (Felsenstein, 1985). Bootstrap confidence values were obtained with 1000 resamplings.

The sequence data reveal that $\mathrm{PG}-02^{\mathrm{T}}$ is a member of the Actinobacteria in the domain Bacteria (Stackebrandt et al., 1997). Pairwise comparison of the $16 \mathrm{~S}$ rRNA gene sequence revealed that strain $\mathrm{PG}-02^{\mathrm{T}}$ was $95 \%$ similar to Propioniferax innocua ATCC $49929^{\mathrm{T}}$ (Pitcher \& Collins, 1991; Yokota et al., 1994) and strains of Microlunatus phosphovorus (Nakamura et al., 1995), less than $95 \%$ similar to the type strains of Luteococcus japonicus and L. sanguinus (Tamura et al., 1994) and Friedmanniella antarctica, F. capsulata and F. spumicola (Schumann et al., 1997; Maszenan et al., 1999b), less than $93 \%$ similar to the type strains of Tessaracoccus bendigoensis (Maszenan et al., 1999a), Propionibacterium propionicum, Propionibacterium avidum, Propionibacterium microaerophilum, Propionibacterium jensenii, Propionibacterium freudenreichii subsp. shermanii, Propionibacterium australiense and Propionibacterium lymphophilum (Charfreitag et al., 1988) and strains of Nocardiodes fulvus, N. luteus, N. albus, N. jensenii, N. dubius and N. kribbensis (Collins et al., 1994; Tamura \& Yokota, 1994) and less than 92\% similar to Micropruina glycogenica $\operatorname{Lg} 2^{\mathrm{T}}$ (Shintani et al., 2000), as shown in Fig. 1.

Using the taxonomic scheme of Stackebrandt et al. (1997), it is clear that strain $\mathrm{PG}-02^{\mathrm{T}}$ fits readily within the suborder
Propionibacterineae. All of the closest related genera show complete concurrence with the 16S rRNA signature nucleotides of the taxonomic scheme of Stackebrandt et al. (1997) for members of the suborder Propionibacterineae with the exception of Micropruina glycogenica, which has A$\mathrm{T}$ instead of G-C at nucleotide positions $987: 1218$, and $T$. bendigoensis and Microlunatus sp. Y-73, which respectively have T-A and A-G instead of A-T at positions 671 : 735 (see Supplementary Table S1 available in IJSEM Online). Further analysis of the 16S rRNA structure of strain PG$02^{\mathrm{T}}$ also concurred with the signature scheme for the family Propionibacteriaceae. However, T. bendigoensis, F. antarctica, Friedmanniella sp. Ellin 171 and F. spumicola have G-T instead of A-T at positions 602:636. At positions $658: 748$, instead of A-T, Micropruina glycogenica has A-A, members of the genus Friedmanniella have G-A and Microlunatus sp. Y-73 has G-T (Supplementary Table S2). On the basis of these signature nucleotides, strain $\mathrm{PG}-02^{\mathrm{T}}$ may belong to a novel genus in the family Propionibacteriaceae. However, the scheme of Stackebrandt et al. (1997) will need modification when more actinobacterial isolates within the suborder Propionibacterineae and family Propionibacteriaceae are characterized.

Strain PG- $02^{\mathrm{T}}$ differs morphologically from members of the genera Luteococcus, Friedmanniella and Tessaracoccus, which occur predominantly as cocci in pairs and tetrads. Even though members of Micropruina and Microlunatus share a similar morphology with strain PG- $02^{\mathrm{T}}$ in that they all occur as single cocci or cocci in pairs, members of both genera are aerobic, while strain PG- $02^{\mathrm{T}}$ is facultatively anaerobic based on growth observed down the stab culture. Furthermore, strain PG- $02^{\mathrm{T}}$ differs from Micropruina glycogenica as it stores polyphosphate instead of intracellular glycogen and does not contain meso- $\mathrm{A}_{2} \mathrm{pm}$ in its peptidoglycan. Distinguishing characteristics of strain $\mathrm{PG}-02^{\mathrm{T}}$ are detailed in Table 2.

Pairwise comparison of $16 \mathrm{~S}$ rRNA gene sequences revealed that the sequence of strain PG- $02^{\mathrm{T}}$ was $95 \%$ similar to those of its closest phylogenetic relatives, Microlunatus phosphovorus and Propioniferax innocua. However, strain $\mathrm{PG}-02^{\mathrm{T}}$ is different from Microlunatus phosphovorus in that it contains the isoprenoid quinone MK-8 $\left(\mathrm{H}_{4}\right)$ and its polar lipids lack phosphatidylinositol. Strain $\mathrm{PG}-02^{\mathrm{T}}$ is also different from Propioniferax innocua as the latter exhibits the characteristic pleomorphic rod morphology, and strain PG- $02^{\mathrm{T}}$ cells lack the polar lipid phosphatidylethanolamine (Table 2). One unusual chemotaxonomic characteristic of strain PG- $02^{\mathrm{T}}$ that differentiates it from members of the genera Luteococcus, Friedmanniella, Tessaracoccus, Propioniferax, Micropruina and Microlunatus is the presence of $\mathrm{i}-\mathrm{C}_{15: 0}$ DMA. 1,1-Dimethyl acetals have been detected in actinobacterial facultative anaerobes such as Propionibacterium freudenreichii and Propionibacterium jensenii within the family Propionibacteriaceae (Kämpfer et al., 2000) and also in the aerobic psychrophiles of the genera Frigoribacterium and Subtercola in the family Microbacteriaceae (Kämpfer 


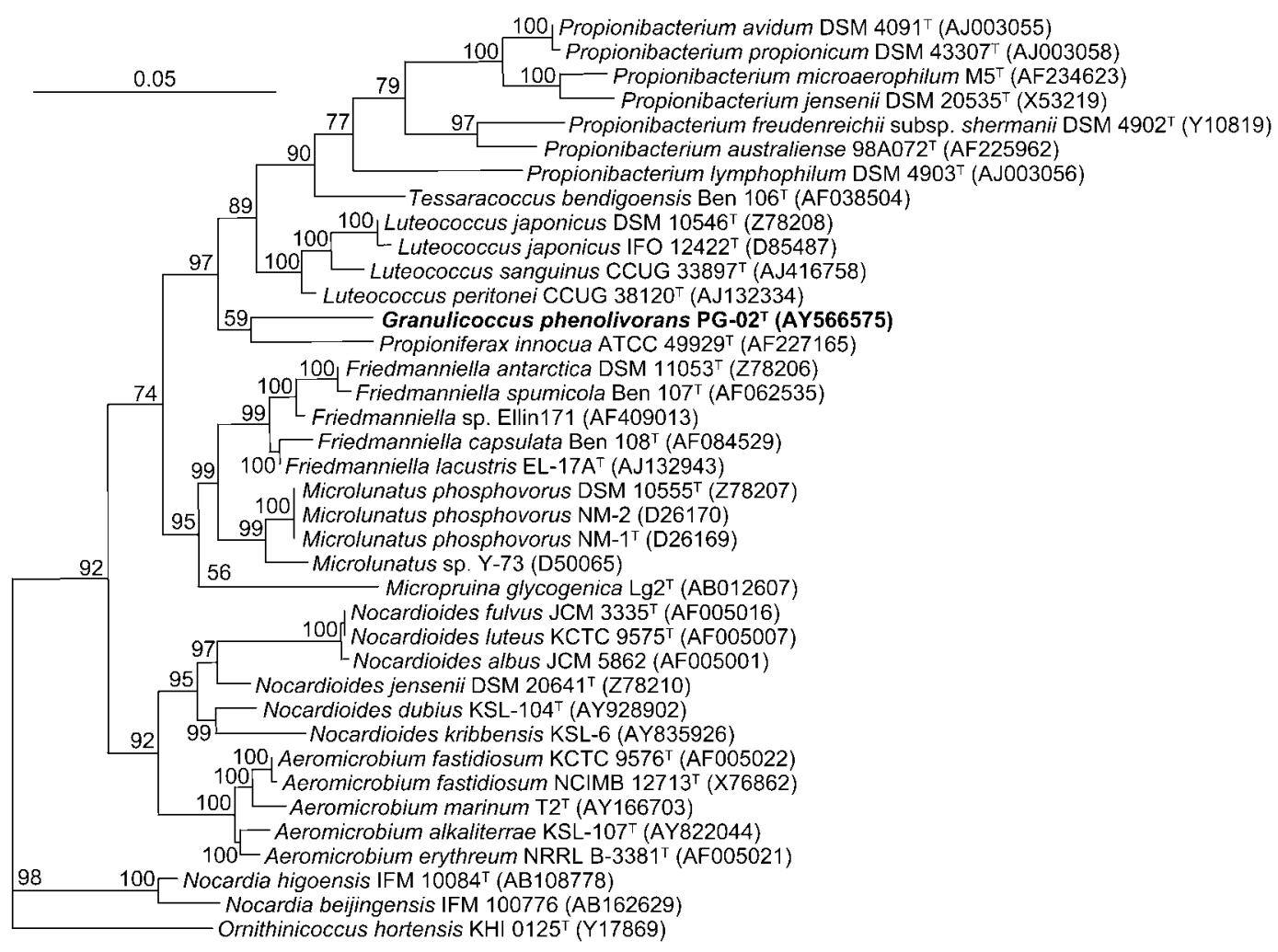

Fig. 1. Phylogenetic tree based on analysis of $16 \mathrm{~S}$ rRNA gene sequences of strain $P G-02^{\top}$ and representatives of the Actinobacteria, constructed from evolutionary distances using the FITCH program. All sequences used in the analysis were obtained from GenBank. Bootstrap values from 100 replications are shown at branching points. Bar, 5 substitutions per 100 nucleotides.

et al., 2000; Männistö et al., 2000). However, in PG-02 ${ }^{\mathrm{T}}$, i- $\mathrm{C}_{15: 0}$ DMA made up $37.4 \%$ of the total cellular fatty acids, a much higher level than has been detected in other organisms. An increase in the i- $\mathrm{C}_{15: 0}$ DMA concentration was noted in Subtercola boreus and Subtercola frigoramans when the growth temperature was lowered from 25 to $4{ }^{\circ} \mathrm{C}$ (Männistö et al., 2000). 1,1-Dimethyl acetals are derived from methanolysis of plasmalogens (alk-1'-enyl glyceryl ethers), which are found in the obligate anaerobes Eubacterium lentum and Megasphaera elsdenii and obligately anaerobic members of the Clostridia and the genera Fusobacterium, Propionibacterium, Subtercola and Frigoribacterium (Jantzen \& Hofstad, 1981; Johnston \& Goldfine, 1994; Kaufman et al., 1990; Verhulst et al., 1987; Kämpfer et al., 2000; Männistö et al., 2000). Kaufman et al. (1990) suggested that 1,1-dimethyl acetal composition may affect cell membrane fluidity in Megasphaera elsdenii.

Based on the presence of $\mathrm{i}-\mathrm{C}_{15: 0}$ DMA in unusually large amounts, together with the other chemotaxonomic properties, phenotypic features and the 16S rRNA gene sequence data presented here, we propose that strain PG- $02^{\mathrm{T}}$ should be classified in a novel genus and species as Granulicoccus phenolivorans gen. nov., sp. nov. within the family Propionibacteriaceae.

\section{Description of Granulicoccus gen. nov.}

Granulicoccus [Gra.nu.li.coc'cus. L. neut. n. granulum a small grain; L. masc. n. coccus a berry; N.L. masc. n. Granulicoccus a coccus from (sludge) granules].

Gram-positive, non-spore-forming cocci, $0.3-1.4 \mu \mathrm{m}$ in diameter (Fig. 2). Contain type A3 $\gamma$ peptidoglycan (LL$\mathrm{A}_{2} \mathrm{pm} \leftarrow$ Gly with alanine at position 1 of the peptide subunit). Menaquinone MK-9 $\left(\mathrm{H}_{4}\right)$ is the major isoprenoid quinone. Polar lipids include diphosphatidylglycerol and phosphatidylglycerol. 13-Methyltetradecanoic acid and 1,1dimethoxy-iso-pentadecane are the major components in whole-cell methanolysates. The genus is a member of the family Propionibacteriaceae. The type species is Granulicoccus phenolivorans.

\section{Description of Granulicoccus phenolivorans sp. nov.}

Granulicoccus phenolivorans (phe.no.li.vo' rans. N.L. neut. n. phenolum phenol; L. part. adj. vorans devouring, consuming; N.L. part. adj. phenolivorans consuming phenol).

In addition to the characteristics described for the genus, results obtained with the Biolog GN and GP systems and 
Table 2. Comparative phenotypic characters of strain $P G-02^{\top}$ and related members of the suborder Propionibacterineae

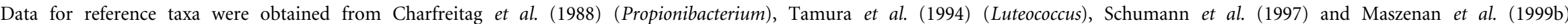

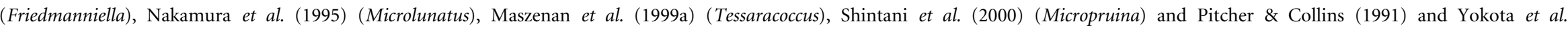
(1994) (Propioniferax). All isolates are Gram-positive. +, Positive; -, negative; ND, no data available.

\begin{tabular}{|c|c|c|c|c|c|c|c|c|}
\hline Character & Propionibacterium & Luteococcus & Friedmanniella & Microlunatus & Tessaracoccus & Micropruina & Propioniferax & Strain PG-02 ${ }^{\mathrm{T}}$ \\
\hline $\mathrm{O}_{2}$ requirement & $\begin{array}{r}\text { Facultative } \\
\text { anaerobes }\end{array}$ & $\begin{array}{r}\text { Facultative } \\
\text { anaerobes }\end{array}$ & Aerobes & Aerobes & $\begin{array}{r}\text { Facultative } \\
\text { anaerobes }\end{array}$ & $\begin{array}{c}\text { Aerobic } \\
\text { chemoorganotrophs }\end{array}$ & $\begin{array}{r}\text { Facultative } \\
\text { anaerobes }\end{array}$ & $\begin{array}{c}\text { Facultative } \\
\text { anaerobe }\end{array}$ \\
\hline $\begin{array}{l}\text { Cell morphology } \\
(\text { size, in } \mu \mathrm{m})\end{array}$ & $\begin{array}{l}\text { Pleomorphic rods } \\
\qquad(0.2-0.8)\end{array}$ & $\begin{array}{l}\text { Cocci, in pairs } \\
\text { and tetrads } \\
(0.7-1.0)\end{array}$ & $\begin{array}{c}\text { Cocci, in packets } \\
\quad(0.5-2.2)\end{array}$ & $\begin{array}{l}\text { Cocci, single and } \\
\text { in pairs }(0.8-2.0)\end{array}$ & $\begin{array}{c}\text { Cocci, in tetrads } \\
\quad(0.5-1.1)\end{array}$ & $\begin{array}{l}\text { Cocci, single } \\
\text { or pairs and } \\
\text { in packets } \\
(0.5-2.2)\end{array}$ & $\begin{array}{l}\text { Pleomorphic } \\
\text { rods }(0.5-1.2)\end{array}$ & $\begin{array}{l}\text { Cocci, } \\
\text { single and } \\
\text { in pairs } \\
(0.3-1.4)\end{array}$ \\
\hline Isolation source(s) & $\begin{array}{l}\text { Human oral cavity, } \\
\text { cervicovaginal } \\
\text { secretion }\end{array}$ & Soil, water & $\begin{array}{c}\text { Antarctic sandstone, } \\
\text { sewage treatment } \\
\text { plant }\end{array}$ & $\begin{array}{l}\text { Sewage } \\
\text { treatment } \\
\text { plant }\end{array}$ & $\begin{array}{l}\text { Sewage } \\
\text { treatment } \\
\text { plant }\end{array}$ & $\begin{array}{l}\text { Laboratory } \\
\text { sequencing } \\
\text { batch reactor }\end{array}$ & $\begin{array}{l}\text { Human } \\
\text { epidermal } \\
\text { surface }\end{array}$ & $\begin{array}{l}\text { Phenol- } \\
\text { degrading } \\
\text { aerobic } \\
\text { granules }\end{array}$ \\
\hline \multicolumn{9}{|l|}{$\begin{array}{l}\text { Growth temperature } \\
\left({ }^{\circ} \mathrm{C}\right)\end{array}$} \\
\hline Optimum & $35-37$ & $26-28$ & $20-25$ & $25-30$ & 25 & 30 & 37 & 30 \\
\hline Range & $30-37$ & $12-38$ & $9-37$ & $5-35$ & $20-37$ & $20-35$ & $10-40$ & $15-37$ \\
\hline \multicolumn{9}{|l|}{$\mathrm{pH}$ for growth } \\
\hline Optimum & ND & ND & $6.0-7.5$ & 7.0 & 7.5 & 7.0 & 7.0 & 7.0 \\
\hline Range & ND & ND & $5.1-8.7$ & $5.0-9.0$ & $5.5-9.3$ & $6.0-8.0$ & ND & $5.0-8.5$ \\
\hline $\begin{array}{l}\text { Presence of } \\
\text { metachromatic } \\
\text { granules }^{\star}\end{array}$ & ND & ND & + , PolyP &,+ PolyP & + , PolyP &,$+ \mathrm{G}$ &,$+ \mathrm{NK}$ & + , PolyP \\
\hline Oxidase & ND & + & - & $+($ weak $)$ & - & + & + & - \\
\hline Catalase & - & + & + & + & + & + & + & + \\
\hline Production of indole & - & - & - & + & - & ND & - & - \\
\hline Production of $\mathrm{H}_{2} \mathrm{~S}$ & + & - & + & ND & - & ND & - & - \\
\hline Major menaquinone(s) & MK-9 $\left(\mathrm{H}_{4}\right)$ & MK-9 $\left(\mathrm{H}_{4}\right)$ & $\begin{array}{l}\text { MK-9 }\left(\mathrm{H}_{4}\right), \text { MK-9 }\left(\mathrm{H}_{2}\right) \\
\text { MK-7 }\left(\mathrm{H}_{4}\right), \text { MK-7 }\left(\mathrm{H}_{2}\right)\end{array}$ & MK-9 $\left(\mathrm{H}_{4}\right)$ & $\begin{array}{r}\text { MK-9 }\left(\mathrm{H}_{4}\right) \\
\text { MK-7 }\left(\mathrm{H}_{4}\right)\end{array}$ & MK-9 $\left(\mathrm{H}_{4}\right)$ & MK-9 $\left(\mathrm{H}_{4}\right)$ & $\begin{array}{r}\text { MK-9 }\left(\mathrm{H}_{4}\right) \\
\text { MK-8 }\left(\mathrm{H}_{4}\right)\end{array}$ \\
\hline $\mathrm{A}_{2} \mathrm{pm} /$ murein type & $\mathrm{LL}-\mathrm{A}_{2} \mathrm{pm} / \mathrm{A} 3-\gamma^{\prime}$ & $\mathrm{LL}-\mathrm{A}_{2} \mathrm{pm} / \mathrm{A} 3-\gamma$ & $\mathrm{LL}-\mathrm{A}_{2} \mathrm{pm} / \mathrm{A} 3-\gamma^{\prime}$ & $\mathrm{LL}-\mathrm{A}_{2} \mathrm{pm} / \mathrm{A} 3-\gamma^{\prime}$ & LL-A ${ }_{2} \mathrm{pm} / \mathrm{A} 3-\gamma^{\prime}$ & meso- $\mathrm{A}_{2} \mathrm{pm}$ & $\mathrm{LL}-\mathrm{A}_{2} \mathrm{pm} / \mathrm{A} 3-\gamma$ & $\mathrm{LL}-\mathrm{A}_{2} \mathrm{pm} / \mathrm{A} 3-\gamma$ \\
\hline Polar lipids $\dagger$ & $\mathrm{ND}$ & PG, DPG, PI, GL & PG, DPG, PI, PL, GL $\ddagger$ & PG, DPG, PI, PL & PG, DPG, PI, PL & $\mathrm{ND}$ & PE, PG, PL, GL & PG, DPG \\
\hline Urease & - & - & + & + & - & ND & + & + \\
\hline Nitrate reduction & + & - & - & + & + & + & + & - \\
\hline $\begin{array}{l}\text { DNA G }+C \text { content } \\
(\mathrm{mol} \%)\end{array}$ & $63-65$ & $66-68$ & $69-74$ & 68 & 74 & 71 & $59-63$ & 69 \\
\hline
\end{tabular}

${ }^{*}$ G, Glycogen; PolyP, polyphosphate; NK, type of granules not known.

$\nmid$ DPG, Diphosphatidylglycerol; GL, unidentified glycolipid; PE, phosphatidylethanolamine; PG, phosphatidylglycerol; PI, phosphatidylinositol; PL, unidentified phospholipid.

$\$$ Present in F. spumicola and F. capsulata. 


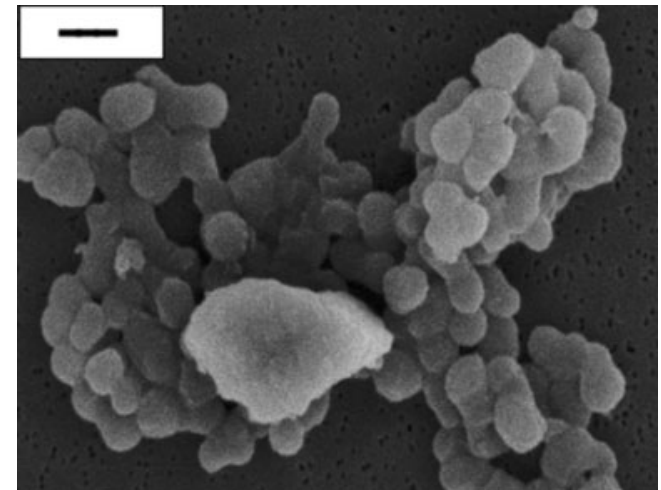

Fig. 2. Scanning electron micrograph of strain $\mathrm{PG}-02^{\top}$ showing cocci in pairs and as single cells. Bar, $1 \mu \mathrm{m}$.

API 20E system show that the type strain can utilize the following components: Tweens 40 and 80 , L-arabinose, $\alpha$-Dglucose, $\alpha$-D-lactose, lactulose, maltose, maltotriose, D-mannose, D-melezitose, D-melibiose, methyl $\alpha$-D-galactoside, methyl $\beta$-D-galactoside, 3 -methyl glucose, methyl $\alpha$-Dglucoside, methyl $\beta$-D-glucoside, psicose, D-raffinose, L-rhamnose, D-ribose, salicin, sedoheptulosan, stachyose, sucrose, D-tagatose, D-trehalose, turanose, D-xylose, myoinositol, D-mannitol, D-sorbitol, xylitol, 2,3-butanediol, glycerol, DL- $\alpha$-glycerol phosphate, glucose 1-phosphate, glucose 6-phosphate, adenosine, AMP, TMP, UMP and fructose 6-phosphate. Acids and their derivatives utilized by the type strain include methyl pyruvate, monomethyl succinate, acetic acid, citric acid, D-galactonic acid lactone, D-gluconic acid, D-glucuronic acid, $\alpha$-, $\beta$ - and $\gamma$-hydroxybutyric acids, $p$-hydroxyphenylacetic acid, itaconic acid, $\alpha$-ketobutyric acid, $\alpha$-ketoglutaric acid, $\alpha$-ketovaleric acid, lactamide, D-lactic acid methyl ester, L- and DL-lactic acid, Dand L-malic acid, propionic acid, pyruvic acid, quinic acid, Dsaccharic acid, sebacic acid, succinic acid, bromosuccinic acid, succinamic acid, $N$-acetylglutamic acid, L-glutamic acid, glycyl L-glutamic acid and L-pyroglutamic acid. The type strain can consume amino compounds including glucuronamide, alaninamide, D-alanine, L-alanine, L-alanyl glycine, L-asparagine, L-phenylalanine, L-proline, L-serine, inosine, uridine, thymidine and putrescine. Gentiobiose is utilized weakly. $\alpha$-Cyclodextrin, $\beta$-cyclodextrin, dextrin, glycogen, inulin, mannan, amygdalin, adonitol, D-arabitol, arbutin, cellobiose, i-erythritol, D-fructose, L-fucose, D-galactose, 2-aminoethanol, $\mathrm{N}$-acetyl-D-galactosamine, $\mathrm{N}$-acetyl-D-glucosamine, $\mathrm{N}$-acetylmannosamine, phenyl ethylamine, deoxyadenosine, L-histidine, hydroxy-L-proline, L-leucine, Lornithine, D-serine, L-threonine, DL-carnitine, D-galacturonic acid, formic acid, D-glucosaminic acid, malonic acid, Laspartic acid, $\gamma$-aminobutyric acid and urocanic acid are not utilized. Enzyme activities detected by both the API ZYM and API 20E systems are alkaline phosphatase, esterase, lipase, leucine arylamidase, valine arylamidase, naphthol-AS-BIphosphohydrolase, $\alpha$-galactosidase, $\beta$-galactosidase, $\beta$-glucuronidase, $\alpha$-glucosidase and $\beta$-glucosidase. Activities of the following enzymes are not detected with API ZYM: acid phosphatase, esterase lipase, cystine arylamidase, trypsin, chymotrypsin, $N$-acetyl- $\beta$-glucosaminidase, $\alpha$-mannosidase and $\alpha$-fucosidase. Activities of $\beta$-galactosidase, urease and gelatinase are detected with API 20E. Arginine dihydrolase, lysine decarboxylase, ornithine decarboxylase and tryptophan deaminase activities are not detected. $\mathrm{H}_{2} \mathrm{~S}$ and indole are not produced. Voges-Proskauer-negative and does not produce acetoin or reduce nitrate to nitrite. Catalase-positive and oxidase-negative. The genomic $\mathrm{G}+\mathrm{C}$ content of the type strain is $69 \mathrm{~mol} \%$.

The type strain, PG- $02^{\mathrm{T}} \quad\left(=\mathrm{ATCC}\right.$ BAA $-1292^{\mathrm{T}}=\mathrm{DSM}$ $\left.17626^{\mathrm{T}}\right)$, was isolated from phenol-degrading aerobic granules.

\section{Acknowledgements}

We thank Professor Dr Hans Trüper for his assistance in naming the organism.

\section{References}

Altschul, S. F., Madden, T. L., Schaffer, A. A., Zhang, J., Zhang, Z., Miller, W. \& Lipman, D. J. (1997). Gapped BLAST and PSI-BLAST: a new generation of protein database search programs. Nucleic Acids Res 25, 3389-3420.

Arai, H., Akahira, S., Ohishi, T., Maeda, M. \& Kudo, K. (1998). Adaptation of Comamonas testosteroni TA441 to utilize phenol: organization and regulation of the genes involved in phenol degradation. Microbiology 144, 2895-2903.

Bossier, P. \& Verstraete, W. (1996). Triggers for microbial aggregation in activated sludge? Appl Microbiol Biotechnol 45, 1-6.

Buck, J. D. (1982). Nonstaining (KOH) method for determination of Gram reactions of marine bacteria. Appl Environ Microbiol 44, 992-993.

Charfreitag, O., Collins, M. D. \& Stackebrandt, E. (1988). Reclassification of Arachnia propionica as Propionibacterium propionicus comb. nov. Int J Syst Bacteriol 38, 354-357.

Collins, M. D., Cockcroft, S. \& Wallbanks, S. (1994). Phylogenetic analysis of a new LL-diaminopimelic acid-containing coryneform bacterium from herbage, Nocardioides plantarum sp. nov. Int J Syst Bacteriol 44, 523-526.

Cote, R. J. \& Gherna, R. L. (1994). Nutrition and medium. In Methods for General and Molecular Bacteriology, pp. 156-178. Edited by P. Gerhardt, R. G. E. Murray, W. A. Wood \& N. R. Kreig. Washington, DC: American Society for Microbiology.

Dapaah, S. Y. \& Hill, G. A. (1992). Biodegradation of chlorophenol mixtures by Pseudomonas putida. Biotechnol Bioeng 40, 1353-1358.

Davì, M. L. \& Gnudi, F. (1999). Phenolic compounds in surface water. Water Res 33, 3213-3219.

Farrell, A. \& Quilty, B. (2002). Substrate-dependent autoaggregation of Pseudomonas putida CP1 during the degradation of monochlorophenols and phenols. J Ind Microbiol Biotechnol 28, 316-324.

Felsenstein, J. (1985). Confidence limits of phylogenies: an approach using the bootstrap. Evolution 39, 783-791.

Hall, T. (1997). BioEdit. Biological sequence alignment editor for Win 95/98/NT/2K/XP. Carlsbad, CA: Ibis Therapeutics.

Hino, H., Watanabe, K. \& Takahashi, N. (1998). Phenol hydroxylase cloned from Ralstonia eutropha strain E2 exhibits novel kinetic properties. Microbiology 144, 1765-1772. 
Jantzen, E. \& Hofstad, T. (1981). Fatty acids of Fusobacterium species: taxonomic implications. J Gen Microbiol 123, 163-171.

Jensen, J. (1996). Chlorophenols in the terrestrial environment. Rev Environ Contam Toxicol 146, 25-51.

Jeong, J. J., Kim, J. H., Kim, C.-K., Hwang, I. \& Lee, K. (2003). 3- and 4-alkylphenol degradation pathway in Pseudomonas sp. strain KL28: genetic organization of the lap gene cluster and substrate specificities of phenol hydroxylase and catechol 2,3-dioxygenase. Microbiology 149, 3265-3277.

Jiang, H.-L., Tay, J.-H., Maszenan, A. M. \& Tay, S. T.-L. (2004). Bacterial diversity and function of aerobic granules engineered in a sequencing batch reactor for phenol degradation. Appl Environ Microbiol 70, 6767-6775.

Johnston, N. C. \& Goldfine, H. (1994). Isolation and characterization of new phosphatidylglycerol acetals of plasmalogens. A family of ether lipids in clostridia. Eur J Biochem 223, 957-963.

Kämpfer, P. \& Kroppenstedt, R. M. (1996). Numerical analysis of fatty acid patterns of coryneform bacteria and related taxa. Can J Microbiol 42, 989-1005.

Kämpfer, P., Rainey, F. A., Andersson, M. A., Nurmiaho Lassila, E.-L., Ulrych, U., Busse, H.-J., Weiss, N., Mikkola, R. \& SalkinojaSalonen, M. (2000). Frigoribacterium faeni gen. nov., sp. nov., a novel psychrophilic genus of the family Microbacteriaceae. Int J Syst Evol Microbiol 50, 355-363.

Kaufman, A. E., Goldfine, H., Narayan, O. \& Gruner, S. M. (1990). Physical studies on the membranes and lipids of plasmalogendeficient Megasphaera elsdenii. Chem Phys Lipids 55, 41-48.

MacKenzie, S. L. (1987). Gas chromatographic analysis of amino acids as the $N$-heptafluorobutyryl isobutyl esters. J Assoc Off Anal Chem 70, 151-160.

Maidak, B. L., Olsen, G. J., Larsen, N., Overbeek, R., McCaughey, M. J. \& Woese, C. R. (1997). The RDP (Ribosomal Database Project). Nucleic Acids Res 25, 109-111.

Männistö, M. K., Schumann, P., Rainey, F. A., Kämpfer, P., Tsitko, I., Tiirola, M. A. \& Salkinoja-Salonen, M. S. (2000). Subtercola boreus gen. nov., sp. nov and Subtercola frigoramans sp. nov., two new psychrophilic actinobacteria isolated from boreal groundwater. Int J Syst Evol Microbiol 50, 1731-1739.

Maszenan, A. M., Seviour, R. J., Patel, B. K. C., Rees, G. N. \& McDougall, B. M. (1997). Amaricoccus gen nov., a gram-negative coccus occurring in regular packages or tetrads, isolated from activated sludge biomass, and descriptions of Amaricoccus veronensis sp. nov., Amaricoccus tamworthensis sp. nov., Amaricoccus macauensis sp. nov., and Amaricoccus kaplicensis sp. nov. Int J Syst Bacteriol 47, 727-734.

Maszenan, A. M., Seviour, R. J., Patel, B. K. C., Schumann, P. \& Rees, G. N. (1999a). Tessaracoccus bendigoensis gen. nov., sp. nov., a Gram-positive coccus occurring in regular packages or tetrads, isolated from activated sludge biomass. Int J Syst Bacteriol 49, 459-468.

Maszenan, A. M., Seviour, R. J., Patel, B. K. C., Schumann, P., Burghardt, J., Webb, R. I., Soddell, J. A. \& Rees, G. N. (1999b). Friedmanniella spumicola sp. nov. and Friedmanniella capsulata sp. nov. from activated sludge foam: Gram-positive cocci that grow in aggregates of repeating groups of cocci. Int J Syst Bacteriol 49, 1667-1680.

MIDI (1999). Sherlock Microbial Identification System, Operating Manual, version 3.0. Newark, DE: MIDI, Inc.

Nakamura, K., Hiraishi, A., Yoshimi, Y., Kawaharasaki, M., Masuda, K. \& Kamagata, Y. (1995). Microlunatus phosphovorus gen. nov., sp. nov., a new gram-positive polyphosphate-accumulating bacterium isolated from activated sludge. Int J Syst Bacteriol 45, 17-22.

Pitcher, D. G. \& Collins, M. D. (1991). Phylogenetic analysis of some LL-diaminopimelic acid-containing coryneform bacteria from human skin: description of Propionibacterium innocuum sp. nov. FEMS Microbiol Lett 84, 295-300.

Rees, G. N., Vasiliadis, G., May, J. W. \& Bayly, R. C. (1992), Differentiation of polyphosphate and poly- $\beta$-hydroxybutyrate granules in an Acinetobacter sp. isolated from activated sludge. FEMS Microbiol Lett 94, 171-173.

Rehfuss, M. \& Urban, J. (2005). Alcaligenes faecalis subsp. phenolicus subsp. nov. a phenol-degrading, denitrifying bacterium isolated from a graywater bioprocessor. Syst Appl Microbiol 28, 421-429.

Schumann, P., Prauser, H., Rainey, F. A., Stackebrandt, E. \& Hirsch, P. (1997). Friedmanniella antarctica gen. nov., sp. nov., an LLdiaminopimelic acid-containing actinomycete from Antarctic sandstone. Int J Syst Bacteriol 47, 278-283.

Selvaratnam, S., Schoedel, B. A., McFarland, B. L. \& Kulpa, C. F. (1997). Application of the polymerase chain reaction (PCR) and reverse transcriptase/PCR for determining the fate of phenoldegrading Pseudomonas putida ATCC 11172 in a bioaugmented sequencing batch reactor. Appl Microbiol Biotechnol 47, 236-240.

Semple, K. T. \& Cain, R. B. (1995). Metabolism of phenols by Ochromonas danica. FEMS Microbiol Lett 133, 253-257.

Shintani, T., Liu, W. T., Hanada, S., Kamagata, Y., Miyaoka, S., Suzuki, T. \& Nakamura, K. (2000). Micropruina glycogenica gen. nov., sp. nov., a new Gram-positive glycogen-accumulating bacterium isolated from activated sludge. Int J Syst Evol Microbiol 50, 201-207.

Smibert, R. M. \& Krieg, N. L. (1994). Phenotypic characterization. In Methods for General and Molecular Bacteriology, pp 607-654. Edited by P Gerhardt, R. G. E. Murray, W. A. Wood \& N. R. Krieg. Washington, DC: American Society for Microbiology.

Soda, S., Ike, M. \& Fujita, M. (1998). Effects of inoculation of a genetically engineered bacterium on performance and indigenous bacteria of a sequencing batch activated sludge process treating phenol. J Ferment Bioeng 86, 90-96.

Stackebrandt, E., Rainey, F. A. \& Ward-Rainey, N. L. (1997). Proposal for a new hierarchic classification system, Actinobacteria classis nov. Int J Syst Bacteriol 47, 479-491.

Tamura, T. \& Yokota, A. (1994). Transfer of Nocardioides fastidiosa Collins and Stackebrandt 1989 to the genus Aeromicrobium as Aeromicrobium fastidiosum comb. nov. Int J Syst Bacteriol 44, 608-611.

Tamura, T., Takeuchi, M. \& Yokota, A. (1994). Luteococcus japonicus gen. nov., sp. nov., a new gram-positive coccus with LLdiaminopimelic acid in the cell wall. Int J Syst Bacteriol 44, 348-356.

Thompson, J. D., Higgins, D. G. \& Gibson, T. J. (1994). CLUSTAL W: improving the sensitivity of progressive multiple sequence alignment through sequence weighting, position-specific gap penalties and weight matrix choice. Nucleic Acids Res 22, 4673-4680.

van Limbergen, H., Top, E. M. \& Verstraete, W. (1998). Bioaugmentation in activated sludge: current features and future perspectives. Appl Microbiol Biotechnol 50, 16-23.

van Schie, P. M. \& Young, L. Y. (1998). Isolation and characterization of phenol-degrading denitrifying bacteria. Appl Environ Microbiol 64, 2432-2438.

Verhulst, A., van Hespen, H., Symons, F. \& Eyssen, H. (1987). Systematic analysis of the long-chain components of Eubacterium lentum. J Gen Microbiol 133, 275-282.

Watanabe, K., Hino, S., Onodera, K., Kajie, S. \& Takahashi, N. (1996). Diversity in kinetics of bacterial phenoloxygenating activity. J Ferment Bioeng 81, 562-565.

Watanabe, K., Teramoto, M., Futamata, H. \& Harayama, S. (1998). Molecular detection, isolation, and physiological characterization of functionally dominant phenol-degrading bacteria in activated sludge. Appl Environ Microbiol 64, 4396-4402. 
Watanabe, K., Teramoto, M. \& Harayama, S. (1999). An outbreak of nonflocculating catabolic populations caused the breakdown of a phenol-digesting activated-sludge process. Appl Environ Microbiol 65, 2813-2819.

Whiteley, A. S. \& Bailey, M. J. (2000). Bacterial community structure and physiological state within an industrial phenol bioremediation system. Appl Environ Microbiol 66, 2400-2407.
Winker, S. \& Woese, C. R. (1991). A definition of the domain Archaea, Bacteria and Eucarya in terms of small ribosomal RNA characteristics. Syst Appl Microbiol 14, 305-310.

Yokota, A., Tamura, T., Takeuchi, M., Weiss, N. \& Stackebrandt, E. (1994). Transfer of Propionibacterium innocuum Pitcher and Collins 1991 to Propioniferax gen. nov. as Propioniferax innocua comb. nov. Int J Syst Bacteriol 44, 579-582. 